\title{
Intelligent flexible disassembly and recycling of used products to support sustainability and total quality management in modern manufacturing industry
}

\author{
P. H. Osanna ${ }^{1}$, M. N. Durakbasa ${ }^{1}$, J. M. Bauer ${ }^{2}$, H. S. Tahirova ${ }^{1}$ \\ \& L. Kraeuter ${ }^{1}$ \\ ${ }^{I}$ Department for Interchangeable Manufacturing and Industrial \\ Metrology, Vienna University of Technology, Wien, Austria \\ ${ }^{2}$ National University of Lomas Zamora, Buenos Aires, Argentina
}

\begin{abstract}
Important changes in the environment, reduced availability of natural resources and the increasing growth of waste means that new concepts and strategies to recycle technical consumer goods, such as household instruments, consumer electronics and passenger cars, are required instead of land filling, burning or steel production. In view of the large quantity and high personnel costs, an advanced disassembly technique is needed using more rational than traditional manual processes and cheaper than highly sophisticated fully automated high technology machines and devices. One of the biggest problems for the recycling or disposal of products besides the growing mass of waste is their complex composition. An economic, sustainable and ecological procedure is necessary to prepare and to refurbish products, therefore the disassembly is the first step to achieving a higher rate of recycling.
\end{abstract}

Keywords: disassembly, waste, life cycle assessment, sustainability, planning, development, recycling, consumer products.

\section{Introduction}

In modern industrial production the very important issues of the protection of environment and sustainability must be taken increasingly into consideration $[1,2]$. Manufacturers of products for every day life - consumer electronics, 
automobiles, house hold devices - are facing increasing demands from consumers, public opinion and governments to minimize the pressure on environment, decrease consumption of raw materials and energy, and reduce pollution and waste $[3,4]$.

The complexity of scrap recycling from the above mentioned consumer products is a strongly interdisciplinary field where there are items such as collection logistics, disassembly, components re-use, recovery of precious and rare materials such as copper, recycling of non-hazardous materials and disposal of hazardous and toxic substances. All these require the coordinated work of interdisciplinary teams $[5,6]$.

European Union Environment Council approved in 1990 the Commission's Strategy for Waste Management, which included ELVs (End of Life Vehicle) as a Priority Waste Stream.

Concerning of the Waste Strategy Priorities the generally accepted hierarchy of priority with respect to waste is:

- prevention,

- recovery,

- disposal.

Within the term recovery the concept includes the re-use of parts, the recycling of material and the recovery of energy.

The Objectives of the European Commission Proposal for automobiles are the following:

- avoidance of waste,

- reduction of landfill demand, and

- reduction of toxicity.

European "Take-Back Law" requires automobile manufacturers to take back all vehicles which were not sold in that country. Voluntary agreements have been widely accepted by industry and the threat of legislation has subsided slightly.

Essential advantages to application of old automobiles are established by the following directives of EU and according to their transformation to the national right:

- The directive 75/442/ European Economic Community of advice from July 15,1975 , about waste.

- The directive 96/61/ European Economic Community of advice from September 24, 1996, about the integrated evasion and reduction of environmental contamination.

- The directive 1999/31/ European Economic Community of advice from April 26, 1999, about gathering waste.

- The directive in 2000/76/ European Economic Community of the European parliament and advice from December 4, 2000, about combustion of waste. 
- The directive in 2000/53/ European Economic Community of the European parliament and advice from September 18, 2000, about old automobiles.

The overall targets for the improved process, which are in line with those proposed by the EU, are the following:

- for a car being scrapped in 2002, a maximum of $15 \%$ of initial weight to go to landfill

- for a car being scrapped in 2015 , a maximum of $5 \%$ of initial weight to go to landfill.

Economic viability is a necessity for the implementation of the improved disposal process under market conditions. If analysis of detailed monitoring information indicates that an action is viable, but direct financial support is required for it to be sustainable, then the means of providing such support will be considered.

Currently, the European Commission is proposing a directive in which the vehicle manufacturer has the prime responsibility for the product. However, the complex nature of vehicles, the length of life, and the other industrial sectors involved subsequently, point to a shared responsibility between all affected parties.

Essential targets in accordance with item 7 of the EU instructions 2000/53/EG about old vehicle are $[4,7]$ :

- Target from 2006:

$85 \%$ recycling

$80 \%$ material recycling

that is a maximum of $15 \%$ disposal.

- $\quad$ Target from 2015:

$95 \%$ recycling

$85 \%$ material recycling

that is a maximum of $5 \%$ disposal.

\section{Life cycle costs}

In the past the cost structure of a product contained only the cost of development, production including quality assurance, marketing, sales and service. As this is mainly influenced by the manufacture of the product it is important to take into consideration the life cycle costs meaning that the real costs in each life stage are added (see Figure 1).

For this purpose a detailed quantitative assessment of expenses for a product must be carried out taking into account the cost contributions.

\subsection{Development costs}

Roughly $5 \%$ of the life cycle costs originate from this stage. On the other side to this small part of the costs between $60 \%$ up to more than $80 \%$ of the total life 
cycle costs are fixed during the development stage. The influences of other stages on the cost level are small compared with those of research and development.

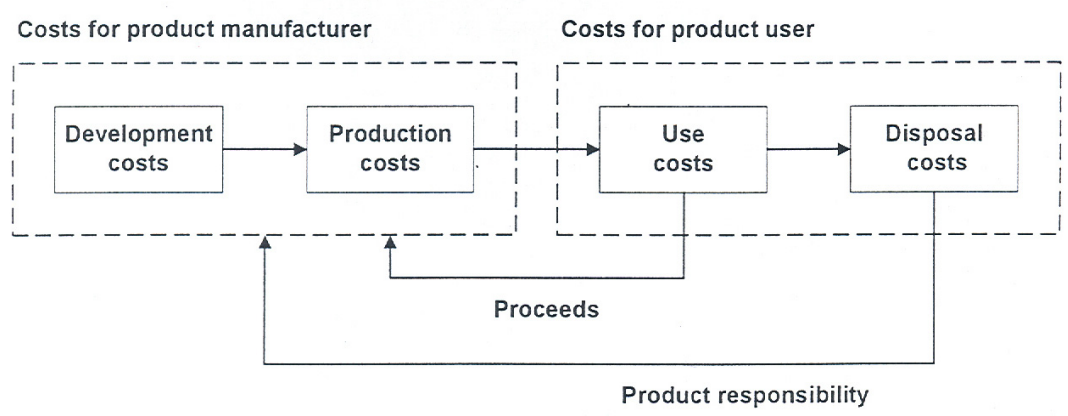

Figure 1: Influences on costs during product life cycle.

\subsection{Production costs}

In any case one can operate on the rough rule which allows the determination of production costs based on costs of different materials used for engineering purposes

\subsection{Use costs}

The costs of the product use phase can be calculated on the basis of the energy costs per time unit that the product is in use.

\subsection{Disposal costs}

The costs of take-back, recycling and final disposal are comprised by the costs of take-back systems, recycling and final disposal processes as well as the returns for the gained secondary raw materials.

In order to account for the different points of time when costs occur, the costs for usage and recycling have to be discounted over the life span of the product.

\section{Life cycle costs}

The challenges for innovative product design are two fold: on the one side having to contain material and energy flows within the product life cycle to close the loop, on the other side reducing the overall consumption of materials and energy to make the loop thinner (see Figure 2). These both should be achieved whilst at the same time the consumer needs are to be identified and met. 


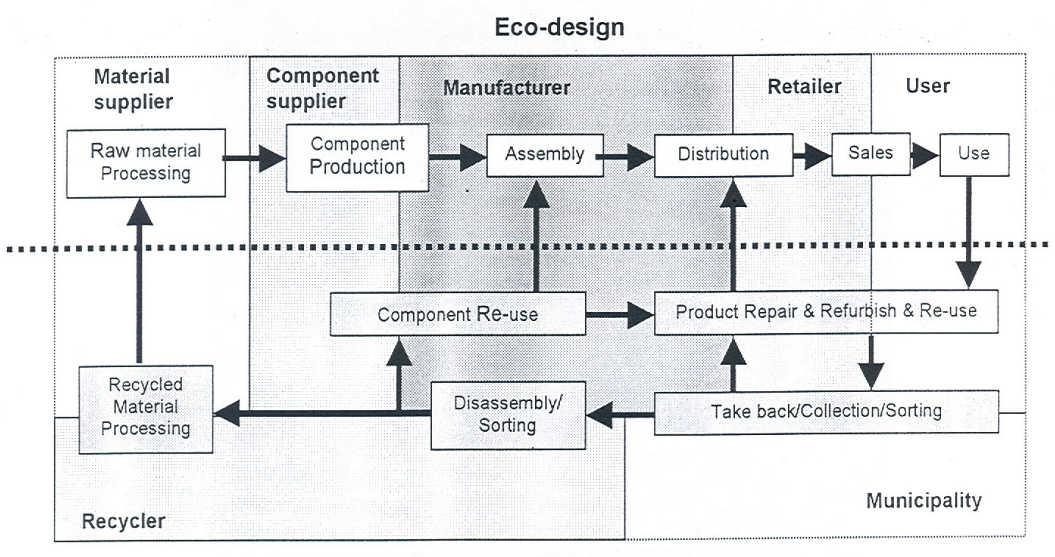

End-of life management

Figure 2: Closed life cycle of consumer products.

The closed life cycle therefore consists of two main streams:

- The "traditional" product life chain (such as production, distribution and use). Introducing environmental concerns in this stream is called "Eco-design".

- Re-using and recycling products, components and materials (such as take back, re-use and recycling). Operation of this stream is called "End-of-life Management".

By disassembly of further non usable parts a considerable reduction of use costs and disposal costs can be achieved. In this respect it is very important that different branches of industry collaborate insofar that different experiences are exchanged as far as different products and different industrialisation are concerned [9].

\section{Principles of a system for intelligent flexible disassembly}

A fixed automated single purpose disassembly system cannot operate economically for the time being $[6,8]$. So it is very important to design such a system with high as possible flexibility. Such a system can be called "Intelligent flexible disassembly cell" (see Figure 3) and it consists of different main modules:

- Disassembly Robot or handling device with special features like path and force control

- Robot Gripper for a wide spectrum of parts with different geometry and dimensions

- Disassembly Tools especially developed for robots

- Components Data Base including data of re-usable and re-manufacturable parts 
- Storage Device for tools and parts

- Transport System and feeding system for products to be disassembled

- Clamping Device and fixture system for parts with different geometry and dimensions

- Manual Disassembly Station for specific tasks

- Quality assurance and quality control module [10]

- Sensors for force, torque, visual recognition, position and distance

- Intelligent Cell Control Unit able to process information from extended sensors.

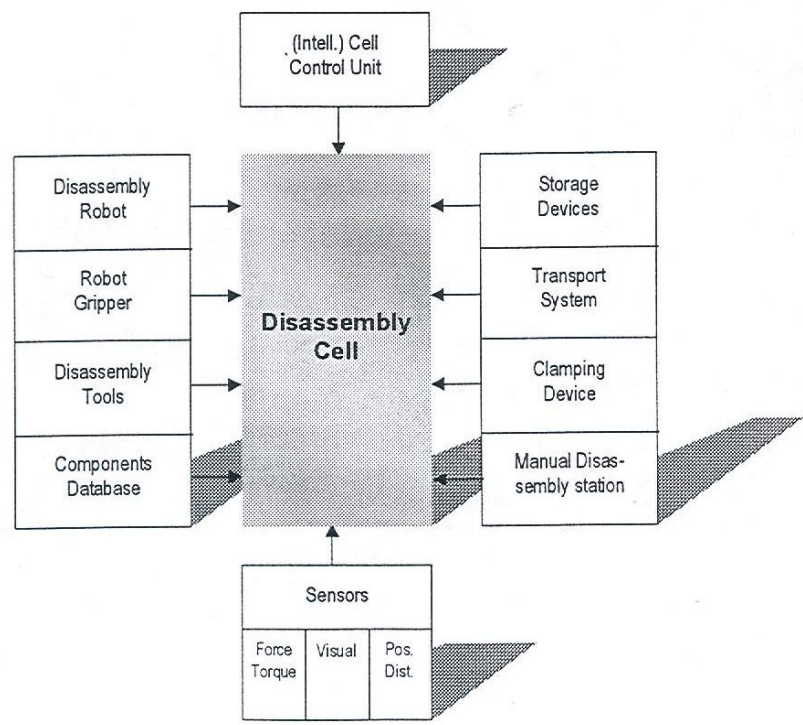

Figure 3: $\quad$ Modules of an "Intelligent flexible disassembly cell".

Flexible semi-automated disassembly can only be carried out economically when the conditions are satisfactory. There must be enough products available at the disassembly cell and the separation technique must be appropriate.

\section{Conclusions}

It can be summarized that the modern society begins to realize that it is necessary to find economical and ecological solutions in order to reduce industrial waste and to preserve natural resources. It has been proved that the only solution is to recycle technical consumer products, as there are household devices, consumer electronics and passenger cars. In this connection, disassembly of products can be referred to as a first step towards efficient recycling and supports strongly sustainability and TQM in European industry. 


\section{References}

[1] EN/ISO 14001: Environmental Management Systems - Specification with Guidance for Use (ISO 14001: 1996).

[2] ISO 14001: 2004: Environmental Management Systems - Requirements with Guidance for Use. ISO Standard, 2004.

[3] Perlewitz, H., Seliger, G., Tomiyana, T., Umeda, Y.: Activities of Japanese Industry for Product Recycling. Proceedings of 2nd International Seminar on Re-use, Eindhoven, NL, 1999.

[4] Directive 2000/53/EC of the European Parliament and of the Council of September 18, 2000, on end-of-life vehicles

[5] Penev, K.D.: Design for Disassembly Systems - A Systematic Approach. PhD Thesis, Eindhoven, NL, 1996.

[6] Broete, S.: Disassembly Systems - Process Analysis and Strategic Considerations. PhD Thesis, Linköping, DK, 1998.

[7] Kopacek, B.: The European WEEE Concept - A Contribution to the Recycling and Re-use of Waste from End-of-life Electrical and Electronic Equipment in Europe. PhD Thesis, Vienna-Wien, A, 1999.

[8] Daichendt, K., Kopacek, P., Zebedin, H.: A New Strategy for a Flexible Semi-automated Disassembling Cell of Printed Circuit Boards. Proceedings of International Conference ISIE'2001, Pusan, Korea, 2001.

[9] Tahirova, H.: TQM, LCA und nachhaltige Entwicklung unterstuetzt durch intelligente flexible Metrologie und Demontage zur Wiederverwertung von gebrauchten Produkten in unterschiedlich industrialisierter Umgebung. PhD Thesis, Vienna-Wien, A, 2006.

[10] Bauer, J.M.: Qualitaetssicherung und die Erstellung von Qualitaetssicherungssystemen an Organisationen fuer die universitaere Ausbildung von IngenieurInnen. PhD Thesis, Vienna-Wien, A, 2003. 